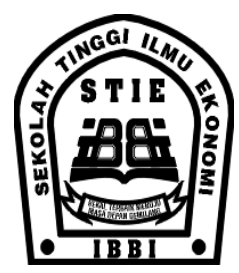

ISSN 1858-3199

JURNAL

MANAJEMEN BISNIS

STIE IBBI

\title{
PENGARUH STRATEGI PROMOSI DAN LOYALITAS PELANGGAN TERHADAP KEPUTUSAN PEMBELIAN
}

\author{
Kendri ${ }^{1)}$, Ahmad Saputra ${ }^{2)}$ \\ Manajemen, STIE IBBI \\ Kendri2013@gmail.com \\ Saputra_damha@yahoo.com
}

\begin{abstract}
ABSTRAK
Penelitian ini bertujuan untuk mengetahui pengaruh strategi promosi dan loyalitas pelanggan terhadap keputusan pembelian pada PT Alfo Citra Abadi.

Jenis penelitian yang digunakan penulis adalah deskriptif kuantitatif. Sumber data dibedakan atas data primer yang diperoleh langsung dari responden melalui wawancara dan pemberian kuesioner dan data sekunder yang mendukung data primer yang diperoleh dari studi dokumentasi guna mendukung penelitian. Teknik analisis data yang digunakan adalah regresi linier berganda. Populasi dalam penelitian ini ada seluruh pelanggan yang membeli produk PT Alfo Citra Abadi Medan. Teknik penarikan sampel menggunakan rumus yang menghasilkan sampel sebanyak 96 orang.

Hasil penelitian menghasilkan sebuah persamaan sebuah persamaan : $\mathrm{Y}=4,194+0,400 \mathrm{X}_{1}+0,483 \mathrm{X}_{2}$. Hasil uji determinan diperoleh nilai sebesar 0,406. Angka ini menunjukkan bahwa kemampuan variabel strategi promosi $\left(\mathrm{X}_{1}\right)$ dan loyalitas pelanggan $\left(\mathrm{X}_{2}\right)$ menjelaskan pengaruhnya terhadap variabel keputusan pembelian $(\mathrm{Y})$ pada PT Alfo Citra Abadi Medan sebesar 40,6\%. Hasil uji serempak diperoleh nilai $F_{\text {hitung }}(33,493)$ lebih besar dibandingkan dengan nilai $\mathrm{F}$ tabel $(3,09)$ yang berarti bahwa strategi promosi dan loyalitas pelanggan secara bersama-sama (serempak) berpengaruh terhadap keputusan pembelian . Hasil uji parsial menunjukkan strategi promosi dan loyalitas pelanggan berpengaruh positif terhadap keputusan pembelian terbukti bahwa thitung komunikasi $(8,990)$ dan thitung loyalitas pelanggan $(2,768)>\mathrm{t} \mathrm{t}_{\text {tabel }}(1,671)$.
\end{abstract}

Kesimpulan penelitian ini adalah strategi promosi dan loyalitas pelanggan berpengaruh terhadap keputusan pembelian pada PT Alfo Citra Abadi Medan.

Kata kunci: strategi promosi, loyalitas pelanggan dan keputusan pembelian. 


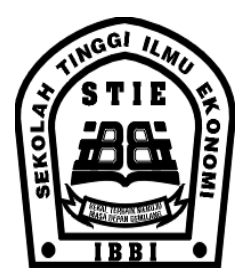

I. PENDAHULUAN

Tingkat persaingan dunia usaha di Indonesia sangat ketat, karena setiap perusahaan senantiasa berusaha untuk dapat meningkatkan pangsa pasar dan meraih konsumen baru. Perusahaan harus dapat menentukan strategi promosi yang tepat agar usahanya dapat bertahan dan memenangi persaingan dalam membina hubungan dengan pelanggan, sehingga tujuan dari perusahaan tersebut dapat tercapai. Pada dasarnya semakin banyak pesaing maka semakin banyak pula pilihan bagi pelanggan untuk dapat memilih produk yang sesuai dengan harapannya. Sehingga konsekuensi dari perubahan tersebut adalah pelanggan menjadi lebih cermat dan pintar menghadapi setiap produk yang diluncurkan.

Persaingan dengan perusahaan sejenis mendorong PT Alfo Citra Abadi untuk merebut pangsa pasar yang ada, sehingga perusahaan dihadapkan ancaman yang cukup serius yang harus di atasi agar dapat terus melangsungkan kehidupannya serta mencapai tujuan yang telah ditetapkan. Keberhasilan perusahaan dalam persaingan dan berkembangnya suatu usaha dapat ditempuh dengan salah satu cara yaitu dengan menerapkan strategi promosi dan meningkatkan loyalitas pelanggan secara optimal sehingga perusahaan dapat mengontrol keberadaan produk di pangsa pasar.

Untuk menunjang pemasaran produk itu sendiri, PT Alfo Citra Abadi Medan tidak hanya dituntut untuk menciptakan berbagai macam variasi produk guna memenuhi keinginan konsumen, tetapi perusahaan juga harus memikirkan strategi promosi yang harus dilakukan dan menjaga loyalitas konsumen sehingga dapat meningkatkan keputusan pembelian konsumen. Bagaimana meningkatkan keputusan pembelian konsumen, hal inilah yang diinginkan PT Alfo Citra Abadi Medan, melalui strategi-strategi promosi dan usaha apa yang dapat dilakukan perusahaan guna meningkatkan loyalitas pelanggan sehingga konsumen melakukan keputusan untuk melakukan pembelian produk perusahaan.
ISSN 1858-3199

JURNAL

MANAJEMEN BISNIS

STIE IBBI
Strategi promosi dilakukan perusahaan dengan menggunakan iklan dan penjualan tatap muka. Media iklan dilakukan sebagai strategi promosi, agar produk perusahaan dapat dikenal oleh banyak masyarakat luas, melalui penjualan tatap muka dengan konsumen maka PT Alfo Citra Abadi Medan dapat mengerti tentang desain yang diminati dan mengenal keinginan konsumen. Sedangkan usaha meningkatkan loyalitas pelanggan dilakukan perusahaan dengan menciptakan berbagai macam variasi produk sehingga konsumen tidak jenuh terhadap produk yang dipasarkan.

Keputusan pembelian yang dilakukan konsumen dapat dipengaruhi strategi promosi dan loyalitas pelanggan. Permasalahan yang dihadapi perusahaan adalah produk yang dihasilkan kurang begitu dikenal masyarakat luas, selanjutnya permasalahan segmen pasar. Segmen pasar perusahaan adalah segmen menengah yang otomatis memiliki jumlah pesaing yang cukup banyak. Hal ini yang menjadi penyebab menurunnya penjualan perusahaan dari tahun ke tahun. Penurunan penjualan yang membuktikan rendahnya keputusan konsumen untuk melakukan pembelian produk perusahaan. Untuk memperbaiki tingkat penjualan yang menurun ini perusahaan menerapkan strategi promosi dan berusaha meningkatkan loyalitas pelanggan.

Strategi promosi yang tepat perlu diterapkan guna mempelajari keadaan pasar dan merebut pasar kembali. Manajer PT Alfo Citra Abadi Medan harus memperhatikan faktor-faktor yang menjadi ancaman atau hambatan bagi usahanya seperti harga jual yang rendah dengan strategi promosi tertentu, model/bentuk produk yang menarik dengan memberikan diskon yang menarik kepada konsumen agar membeli produknya. Di dalam menghadapi ancaman tersebut perusahaan akan menyusun strategi promosi dan cara meningkatkan loyalitas pelanggan yang lebih handal guna meningkatkan penjualan produk yang menurun beberapa tahun terakhir ini.

Berdasarkan uraian di atas, maka dapat dirumuskan masalah yaitu Bagaimana pengaruh 


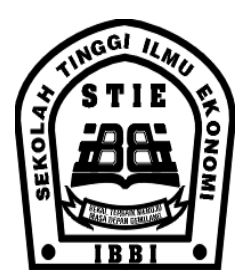

strategi promosi dan loyalitas pelanggan terhadap Keputusan Pembelian pada PT Alfo Citra Abadi Medan?

Adapun tujuan penelitian ini ialah untuk mengetahui pengaruh strategi promosi dan loyalitas pelanggan terhadap keputusan pembelian pada PT Alfo Citra Abadi.

\section{Kajian Literatur}

\section{A. Strategi Promosi}

Menurut Rangkuti (2004:13), "Strategi merupakan alat untuk mencapai tujuan perusahaan dalam kaitannya dengan tujuan jangka panjang, program tindak lanjut, serta prioritas alokasi sumber daya”. Sedangkan menurut Kotler (2005:91), strategi adalah "Suatu rencana permainan untuk mencapai sasaran yang dinginkan dari suatu unit bisnis".

Menurut Swastha dan Irawan (2008: 349): Promosi adalah "Arus informasi atau persuasi satu arah yang dibuat untuk mengarahkan seseorang atau organisasi kepada tindakan menciptakan pertukaran dalam pemasaran".

Menurut Sigit (2007: 101): "Promosi adalah aktivitas-aktivitas sebuah perusahaan yang dirancang untuk memberi informasi, membujuk, atau mengingatkan pihak lain tentang perusahaan yang bersangkutan dengan barang-barang serta jasa-jasa yang ditawarkan olehnya".

Menurut Moekijat (2000 : 443) : "Strategi promosi adalah kegiatan perusahaan untuk mendorong penjualan dengan mengarahkan komunikasi-komunikasi yang meyakinkan kepada para pembeli."

Sedangkan menurut Lamb, Hair, McDaniel (2001 : 146) : "Strategi promosi adalah rencana untuk penggunaan yang optimal dari elemen-elemen promosi : periklanan, hubungan masyarakat, penjualan pribadi dan promosi penjualan".

\section{B. Variabel- Variabel Strategi Promosi}

Menurut Lamb, Hair, McDaniel (2001 :147), "Bauran promosi adalah kombinasi dari alat promosi termasuk periklanan, hubungan masyarakat, dan promosi penjualan yang digunakan untuk
ISSN 1858-3199

JURNAL

MANAJEMEN BISNIS

STIE IBBI

mencapai pasar sasaran dan memenuhi tujuan organisasi secara keseluruhan".

Menurut Kotler dan Armstrong (2002:656) variabel-variabel yang ada di dalam Promotional Mix ada lima, yaitu:

a. penjualan (Sales Promotion)

Insentif jangka pendek untuk mendorong pembelian atau penjualan suatu produk atau jasa.

d. Hubungan masyarakat (Public Relation)

Membangun hubungan baik dengan publik terkait untuk memperoleh dukungan, membangun "citra perusahaan" yang baik dan menangani atau menyingkirkan gosip, cerita dan peristiwa yang dapat merugikan.

e. Pemasaran langsung (Direct Marketing)

Komunikasi langsung dengan pelanggan yang diincar secara khusus untuk memperoleh tanggapan langsung.

Dari definisi di atas dapat disimpulkan bahwa strategi promosi terdiri dari:

1. Strategi Promosi Periklanan

2. Strategi Promosi Penjualan

3. Strategi Promosi Pemasaran Langsung

4. Strategi Promosi Hubungan Masyarakat dan Publisitas

5. Strategi Promosi Penjualan Pribadi

\section{Strategi Promosi Periklanan}

Pengertian periklanan menurut Lupioyadi

(2003 : 108) adalah "Merupakan salah satu

komunikasi impersonal (Impersonal

Communication) yang digunakan oleh perusahaan baik barang atau jasa".

Lamb, Hair, McDaniel (2001 : 147)

menyatakan bahwa "Periklanan merupakan komunikasi bukan pribadi, satu arah mengenai sebuah produk atau organisasi yang dibayar oleh seorang pemasar".

Sedangkan peranan periklanan dalam pemasaran produk atau jasa adalah untuk membangun kesadaran (Awareness) terhadap keberadaan jasa yang ditawarkan, untuk menambah pengetahuan konsumen tentang jasa yang ditawarkan, untuk membujuk calon konsumen untuk membeli atau menggunakan jasa tersebut, dan untuk 


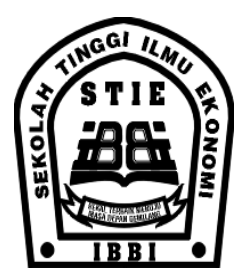

membedakan diri perusahaan satu dengan perusahaan lain (Sifferentiate The Service) yang mendukung Positioning jasa.

Adapun fungsi utama iklan adalah :

- Informative; menginformasikan khalayak mengenai seluk beluk produk.

- Persuading; mempengaruhi khalayak untuk membeli.

- Reminding; menyegarkan informasi yang telah diterima khalayak.

- Entertainment; menciptakan suasana yang menyenangkan sewaktu khalayak menerima dan mencerna informasi.

Sementara itu sifat - sifat iklan adalah sebagai berikut :

- Public Presentation; iklan memungkinkan setiap orang menerima pesan yang sama tentang produk yang diiklankan.

- Pervasiveness; pesan iklan yang sama dapat diulang - ulang untuk memantapkan penerimaan informasi.

- Amplified Expressiveness; iklan mampu mendramatisasi perusahaan dan produknya melalui gambar dan suara untuk menggugah dan mempengaruhi perasaan khalayak.

- Impersonality; iklan tidak bersifat memaksa khalayak untuk memperhatikan dan menanggapinya, karena merupakan komunikasi yang monolog (satu arah).

\section{Strategi Promosi Penjualan}

Lupiyoadi (2001 : 109) menyatakan bahwa "Promosi penjualan adalah semua kegiatan yang dimaksudkan untuk meningkatkan arus barang atau jasa dari produsen sampai pada penjualan akhirnya. Point of Sales Promotion terdiri dari brosur, Information Sheets, dan lain-lain".

Promosi penjualan bertujuan untuk merangsang tanggapan pembeli yang cepat (Quick Buying Response) yang antara lain adalah perlombaan, pemberian hadiah, kombinasi penawaran, kupon, dan potongan harga untuk konsumen.

Daya tarik pokok dari promosi konsumen adalah hasrat untuk tawar menawar (Bargain) atau untuk mendapatkan sesuatu secara cuma - cuma. Yang erat kaitannya dengan ini adalah berbagai tipe
ISSN 1858-3199

JURNAL

MANAJEMEN BISNIS

STIE IBBI

promosi perdagangan seperti barang - barang gratis, upah (Allowances), dan potongan - potongan khusus yang bertujuan untuk mempengaruhi kerjasama penjualan lagi (Reseller Cooperation).

Melalui promosi penjualan, perusahaan dapat menarik pelanggan baru, mempengaruhi pelanggannya untuk mencoba produk baru, mendorong pelanggan lebih banyak, menyerang aktivitas promosi pesaing, meningkatkan Impulse Buying (pembelian tanpa rencana sebelumnya), atau mengupayakan kerjasama yang lebih erat dengan pengecer.

Secara umum tujuan dari promosi penjualan

1. Meningkatkan permintaan dari para pemakai industrial dan/atau konsumen akhir.

2. Meningkatkan kinerja perusahaan

3. Mendukung dan mengkoordinasikan kegiatan personal selling dan iklan.

Sifat - sifat promosi penjualan adalah :

a. Komunikasi; mampu menarik perhatian dan memberi informasi yang memperkenalkan pelanggan kepada produk.

b. Insentif; memberikan keistimewaan dan rangsangan yang bernilai bagi pelanggan.

c. Undangan; mengundang khalayak untuk membeli saat itu juga.

\section{Strategi Promosi Pemasaran Langsung}

Bila penjualan personal berupaya mendekati pembeli, iklan berupaya memberitahu dan mempengaruhi pelanggan, promosi penjualan berupaya mendorong pembelian dan Public Relations membangun dan memelihara citra perusahaan, maka pemasaran langsung memadatkan semua kegiatan tersebut dalam jumlah penjualan langsung tanpa perantara.

Menurut Moekijat (2000 : 123), "Direct Selling (penjualan langsung) adalah penjualan di mana pengusaha melampaui para pedagang besar dan menjual produknya langsung kepada pedagangpedagang eceran, atau dapat diartikan juga secara luas sebagai penjualan langsung oleh produsen kepada konsumen".

\section{Hubungan Masyarakat dan Publisitas}




\section{ISSN 1858-3199 \\ JURNAL \\ MANAJEMEN BISNIS \\ STIE IBBI}

Menurut Lamb, Hair McDaniel (2001 : 148), "Hubungan masyarakat merupakan fungsi pemasaran yang mengevaluasi sikap publik, identifikasi area di dalam organisasi yang masyarakat mungkin tertarik dan menjalankan suatu program tindakan untuk memperoleh pemahaman dan penerimaan masyarakat".

Pengertian yang timbal balik itu menuntut penghargaan terhadap kekuatan dan kelemahan, peluang, sasaran dan masalah - masalah yang dihadapi organisasi, juga menuntut pengakuan atau penerimaan terhadap kebutuhan setiap kelompok yang mempunyai kepentingan didalamnya.

Kegiatan - kegiatan Public Relations meliputi hal-hal berikut :

\section{Press Relations}

Tujuan hubungan dengan pers adalah untuk memberikan informasi yang pantas/layak dimuat di surat kabar agar dapat menarik perhatian publik terhadap seseorang, produk, jasa atau organisasi.

2. Product Publicity

Aktivitas ini meliputi upaya untuk

mempublikasikan produk - produk tertentu.

3. Corporate Communication

Kegiatan ini mencakup komunikasi internal dan eksternal, serta mempromosikan pemahaman tentang organisasi.

\section{Lobbying}

Lobbying merupakan usaha untuk bekerjasama dengan pembuat undang-undang dan pejabat pemerintah sehingga perusahaan mendapatkan informasi-informasi penting yang berharga. Bahkan kadangkala juga dimaksudkan untuk mempengaruhi keputusan yang akan diambil.

5. Counseling

Aktivitas ini dilakukan dengan jalan memberi saran dan pendapat kepada manajemen mengenai masalah yang berkaitan dengan publik dan mengenai posisi dan citra perusahaan.

\section{Penjualan Personal}

Penjualan personal (wiraniaga) mempunyai peranan yang penting dalam pemasaran produk/jasa, karena :

1. Interaksi secara personal antar penyedia jasa dan konsumen sangat penting.
2. Jasa tersebut disediakan oleh orang bukan oleh mesin.

3. Orang merupakan bagian dari produk jasa.

Sifat penjualan personal dapat dikatakan lebih luwes karena tenaga penjual dapat secara langsung menyesuaikan penawaran penjualan dengan kebutuhan dan perilaku masing - masing calon pembeli. Selain itu, tenaga penjual dapat segera mengetahui reaksi calon pembeli terhadap penawaran penjualan, sehingga dapat mengadakan penyesuaian - penyesuaian di tempat pada saat itu juga. adalah :

Adapun sifat - sifat penjualan personal

- Personal Confrontation, yaitu adanya hubungan yang hidup, langsung dan interaktif antara dua orang atau lebih.

- Cultivation, yaitu sifat yang memungkinkan berkembangnya segala macam hubungan, mulai dari sekedar hubungan jual beli sampai dengan suatu hubungan yang lebih akrab.

- Response, yaitu situasi yang seolah-olah mengharuskan pelanggan untuk mendengar, memperhatikan dan menanggapi.

Aktivitas penjualan personal memiliki beberapa fungsi yaitu :

- Prospecting, yaitu mencari pembeli dan menjalin hubungan dengan mereka.

- Targeting, yaitu mengalokasikan kelangkaan waktu penjual demi pembeli.

- Communicating, yaitu memberi informasi mengenai produk kepada pelanggan.

- Selling, yaitu mendekati, mempresentasikan dan mendemonstrasikan, mengatasi penolakan, serta menjual produk kepada pelanggan.

- Servicing, yaitu memberikan berbagai jasa dan pelayanan kepada pelanggan.

- Information Gathering, yaitu melakukan riset dan intelijen pasar.

- Allocating, yaitu menentukan pelanggan yang akan dituju.

Perbedaan iklan dengan kewiraniagaan adalah dalam hal penyampaian pesan, yaitu pesan itu disampaikan dengan kontak pribadi, sedangkan pada iklan pesan itu disampaikan dengan penyajian melalui media massa, media non 


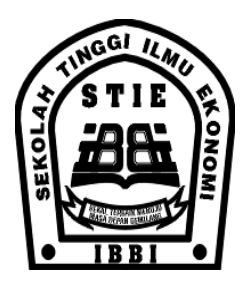

pribadi seperti surat kabar, majalah, televisi, radio dan lain-lain. Oleh karena alasan inilah, para wiraniaga dapat menyesuaikan piranha dengan kebutuhan, mina dan tanggapan dari calon pembeli.

\section{Indikator Strategi Promosi}

Berdasarkan uraian di atas, indikator promosi yang digunakan dalam penelitian ini, adalah (Kotler, 2005:246):

1. Jangkauan promosi

Persentase audiens sasaran yang diekspos sekurang-kurangnya satu kali dengan pesan pemasang iklan selama jangka waktu tertentu.

2. Kuantitas penayangan iklan di media promosi Jumlah waktu rata-rata, dalam periode empat minggu di mana para anggota audiens sasaran diekspos kepada sarana media yang termasuk dalam jadwal media tertentu.

3. Kualitas penyampaian pesan dalam penayangan iklan di media promosi

Maksud, tujuan, dan informasi yang ingin disampaikan dalam penayangan iklan produk

\section{Loyalitas Pelanggan}

Menurut Oliver (2007:392), loyalitas pelanggan adalah "Komitmen untuk bertahan secara mendalam dengan melaksanakan pembelian ulang/berlangganan kembali dengan produk /jasa terpilih secara konsisten dimasa yang akan datang, meskipun pengaruh situasi dan usaha pemasaran mempunyai potensi yang menyebabkan perubahan perilaku".

Menurut Hasan (2008:83), " Loyalitas pelanggan adalah orang yang membeli, khususnya yang membeli secara teratur dan berulang-ulang. Pelanggan merupakan seseorang yang terus menerus dan berulang kali datang ke suatu tempat yang sama untuk memuaskan keinginannya dengan memiliki suatu produk atau mendapatkan suatu jasa dan membayar produk atau jasa tersebut".

Pengertian loyalitas pelanggan menurut Tjiptono (2005:110): "Loyalitas pelanggan adalah komitmen pelanggan terhadap suatu merek, toko, pemasok berdasarkan sikap yang sangat positif dan tercermin dalam pembelian ulang yang konsisten".
ISSN 1858-3199

JURNAL

MANAJEMEN BISNIS

STIE IBBI

Sedangkan menurut Tunggal (2008:6) menyatakan bahwa: "Customer Loyalty adalah kelekatan pelanggan pada suatu merek, toko, pabrikan, pembelian jasa, atau entitas lain berdasarkan sikap yang menguntungkan dan tanggapan yang baik seperti membeli ulang".

Griffin (2002:4) menyatakan: "Konsep loyalitas lebih mengarah kepada perilaku (Behaviour) dibandingkan dengan sikap (Attitude) dan seorang konsumen yang loyal akan memperhatikan perilaku pembelian yang didefinisikan sebagai pemebeli yang teratur dan diperhatikan sepanjang waktu oleh beberapa unit pembuatan keputusan".

Loyalitas dari pelanggan terhadap suatu produk ataupun perusahaan hendaknya terus dipertahankan, karena pelanggan yang loyal merupakan aset yang sangat berharga bagi perusahaan, sementara itu untuk mempertahankan loyalitas pelanggan, Griffin (2002:42), menyarankan perusahaan untuk melakukan hal-hal berikut:

1. Memberikan keunggulan operasi

2. Membentuk kedekatan dengan pelanggan

3. Kepemimpinan multi produk

4. Meriset pelanggan

5. Melatih dan memotivasi staf untuk loyal

6. Membuat data pelanggan, menyediakan layanan pelanggan gratis

7. Melakukan Relationship Marketing

Menurut Bramson (2005:2), loyalitas

konsumen merupakan suatu konsep yang mencakup lima faktor:

1. Pengalaman konsumen dengan kepuasan utuh ketika melakukan transaksi dengan anda.

2. Kesediaan untuk mengembangkan hubungan dengan anda dan dengan perusahaan anda.

3. Kesediaan untuk menjadi pembeli setia.

4. Kesediaan untuk merekomendasikan anda kepada orang lain.

5. Penolakan untuk berpindah pada pesaing.

Menurut Griffin (2002:44), karakteristik pelanggan yang loyal adalah sebagai berikut :

a. Melakukan pembelian ulang secara teratur (Makes Reguler Repeat Purchase).

Loyalitas lebih mengacu pada wujud perilaku dari unit-unit pengambilan keputusan untuk 


\section{ISSN 1858-3199 \\ JURNAL \\ MANAJEMEN BISNIS \\ STIE IBBI}

melakukan pembelian secara terus menerus terhadap barang/jasa suatu perusahaan yang dipilih. Tingkat kepuasan terhadap took akan mempengaruhi mereka untuk membeli kembali

b. Membeli di luar lini produk/jasa (Purchases Across Product and Service Lines).

Membeli di luar lini produk dan jasa artinya keinginan untuk membeli lebih dari produk dan jasa yang telah ditawarkan oleh perusahaan. pelanggan yang sudah percaya pada perusahaan dalam suatu urusan maka akan percaya juga untuk urusan lain.

c. Mereferensi toko kepada orang lain, artinya menarik pelanggan baru untuk perusahaan (Refers Other).

Pelanggan yang loyal dengan sukarela merekomendasikan perusahaan kepada temanteman dan rekannya.

d. Menunjukkan kekebalan daya tarik dari pesaing (Demonstrates Animmunity to The Full of The Competition).

Tidak mudah terpengaruh oleh tarikan persaingan perusahaan sejenis lainnya.

Berdasarkan pengertian yang ada, dapat disimpulkan, bahwa loyalitas konsumen merupakan kesetiaan konsumen terhadap perusahaan atau suatu produk tertentu dengan disertai tindakan untuk membeli kembali dan konsumen bersedia mengembangkan hubungan kembali.

\section{E. Keputusan Pembelian}

Menurut Assauri (2004:141) bahwa: "Keputusan pembelian adalah suatu proses pengambilan keputusan akan pembelian yang mencakup penentuan apa yang akan dibeli atau tidak melakukan pembelian dan keputusan itu diperoleh dari kegiatan-kegiatan sebelumnya".

Menurut Kotler (2005;223) : “ Keputusan Pembelian yaitu :beberapa tahapan yang dilakukan oleh konsumen sebelum melakukan keputusan pembelian suatu produk".

Menurut Chapman dan Wahlers (1999: 65) : "Keputusan Pembelian adalah sebagai keinginan konsumen untuk membeli suatu produk. Konsumen akan memutuskan produk yang akan dibeli berdasarkan persepsi mereka terhadap produk tersebut berkaitan dengan kemampuan produk tersebut dalam memenuhi kebutuhannya".

Dalam keputusan pembelian/membeli barang konsumen ada lebih dari dua pihak yang terlibat dalam proses pertukaran atau pembeliannya. Kegiatan keputusan pembelian meliputi; pilihan akan produk, merek, pemasok, penentuan saat pembelian, jumlah pembelian. Umumnya ada lima macam peranan yang dapat dilakukan seseorang. Ada kalanya kelima peran ini dipegang oleh satu orang, namun sering kali pula peranan tersebut dilakukan beberapa orang. Pemahaman mengenai masing-masing peranan ini sangat berguna dalam rangka memuaskan kebutuhan dan keinginan konsumen. Kelima peran tersebut menurut Kotler (2005 :225) meliputi:

1. Pemrakarsa (Initiator), yaitu orang yang pertama kali menyadari adanya keinginan atau kebutuhan yang belum terpenuhi dan mengusulkan ide untuk membeli suatu barang atau jasa tertentu.

2. Pemberi pengaruh (Influencer), yaitu orang yang pandangan, nasihat atau pendapat-pendapatnya mempengaruhi keputusan pembelian.

3. Pengambil keputusan (Decider), yaitu orang yang menentukan keputusan pembelian.

4. Pembeli (Buyer), yaitu orang yang melakukan pembelian aktual.

5. Pemakai (User), yaitu orang yang mengkonsumsi atau menggunakan barang atau jasa yang dibeli.

\section{F. Proses Pengambilan Keputusan}

Proses pengambilan keputusan dalam pembelian produk barang dan jasa sangat dipengaruhi oleh perilaku konsumen itu sendiri. Kotler (2005:257) mengemukakan bahwa proses pengambilan keputusan membeli melalui lima tahap yaitu:

1. Pengenalan masalah

Proses pembelian dimulai ketika pembeli menyadari adanya masalah atau kebutuhan. Pembeli merasakan adanya perbedaan antara keadaan aktual dengan keadaan yang diinginkan.

2. Pencarian informasi

Seorang konsumen yang mulai tergugah minatnya mungkin akan mencari banyak informasi. 


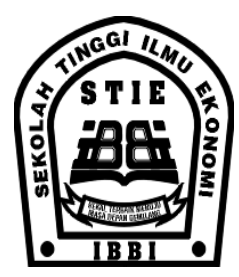

Salah satu yang menjadi perhatian pokok pemasar adalah sumber informasi utama yang dicari konsumen dan pengaruh relatifnya terhadap keputusan pembelian berikutnya.

Sumber-sumber informasi konsumen terdiri dari empat kelompok yaitu:

a. Sumber pribadi : keluarga, teman, tetangga, dan kenalan

b. Sumber komersial : Iklan, wiraniaga, pedagang, perantara, kemasan, pajangan

c. Sumber publik : Media masa, organisasi

d. Sumber pengalaman : Penanganan, pemeriksaan, penggunaan produk

Melalui pengumpulan informasi, konsumen mengetahui merek-merek yang bersaing dan keistimewaan masing-masing merek.

3. Evaluasi alternatif

Tahap ini terdiri dari dua tindakan yaitu menetapkan tujuan pembelian dan menilai serta mengadakan seleksi terhadap alternatif pembelian berdasarkan tujuan pembelian. Setelah tujuan pembelian ditetapkan, konsumen perlu mengidentifikasikan alternatif-alternatif seperti uang, informasi, waktu dan resiko kesalahan dalam memilih.

4. Keputusan pembelian

Disini konsumen harus memutuskan dari setiap komponen pembelian, apa yang mereka beli, bagaimana membeli, atau dimana membeli.

5. Perilaku purna beli

Setelah membeli produk, konsumen akan merasakan tingkat kepuasan atau ketidakpuasan tertentu. Apabila konsumen merasa puas akan produk tersebut maka konsumen akan melakukan pembelian ulang, dan bahkan menginformasikan kepada pelanggan lain, tetapi apabila konsumen tidak puas dengan produk tersebut maka konsumen akan kecewa dan tidak melakukan pembelian lagi pada produk tersebut.

Proses pengambilan keputusan yang luas merupakan jenis pengambilan keputusan yang paling lengkap, bermula dari pengenalan masalah konsumen yang dapat dipecahkan melalui pembelian beberapa produk. Untuk keperluan ini, konsumen mencari informasi tentang produk atau merek tertentu dan mengevaluasi seberapa baik masing-
ISSN 1858-3199

JURNAL

MANAJEMEN BISNIS

STIE IBBI

masing alternatif tersebut dapat memecahkan masalahnya. Evaluasi produk atau merek akan mengarah kepada keputusan pembelian. Selanjutnya konsumen akan mengevaluasi dari hasil keputusannya, proses pengambilan keputusan yang luas terjadi untuk kepentingan khusus bagi konsumen atau untuk pengambilan keputusan yang membutuhkan tingkat keterlibatan tinggi. Tingkat keterlibatan merupakan karakteristik konsumen, bukan karakteristik produk sebagaimana yang sering disalah artikan. Konsumen dikatakan mempunyai tingkat keterlibatan yang tinggi jika dalam membeli suatu produk/jasa, mereka meluangkan cukup banyak waktu, perhatian dan usaha untuk membandingkan berbagai merek dan toko ( Tjiptono, 2005:20).

Sedangkan menurut Swasta dan Handoko (2000:111) adalah

a. Lokasi penjual yang strategis

Dari segi lokasi, pembeli akan memilih lokasi yang benar-benar strategis dan tidak membutuhkan terlalu banyak waktu, tenaga, dan biaya, seperti: mudah dijangkau, dekat dengan fasilitas umum, atau mungkin dekat dengan jalan raya, sehingga lokasi ini dapat mendukung faktor yang lain.

b. Pelayanan yang baik

Bagi konsumen yang ingin membeli suatu produk, pelayanan yang diberikan pada saat memilih produk sampai terjadinya transaksi pembelian sangatlah berpengaruh terhadap jadi tidaknya pembelian yang dilakukan oleh konsumen. Pelayanan yang kurang baik akan menimbulkan rasa tidak puas yang dirasakan oleh konsumen yang selanjutnya akan mempengaruhi tingkat penjualan pada waktu berikutnya.

c. Kemampuan tenaga penjual

Dalam suatu kegiatan usaha (penjualan), tidak terlepas dari tenaga kerja baik tenaga kerja mesin maupun tenaga kerja manusia. Tenaga kerja merupakan faktor utama dalam perusahaan sehingga diperlukan sejumlah tenaga kerja yang berkemampuan dan mempunyai keterampilan tertentu yang sesuai 


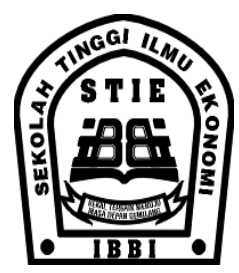

dengan kebutuhan perusahaan untuk mendukung kegiatan penjualan.

d. Iklan dan promosi

Iklan dan promosi merupakan salah satu faktor penentu keberhasilan suatu program pemasaran. Betapapun berkualitasnya suatu produk, bila konsumen belum pernah mendengarnya dan tidak yakin produk itu akan berguna bagi mereka, maka mereka tidak akan membelinya.

e. Penggolongan barang

Penggolongan barang menjadi faktor pertimbangan bagi konsumen yang melakukan kegiatan pembelian. Penggolongan barang yang tepat dan rapi akan memudahkan konsumen dalam melakukan pembelian.

\section{G. Penelitian Terdahulu}

Tabel 1

Penelitian Terdahulu

\begin{tabular}{|c|c|c|c|c|}
\hline $\begin{array}{l}\mathrm{N} \\
\mathrm{O}\end{array}$ & $\begin{array}{c}\text { Penelit } \\
\text { i } \\
\text { (tahun } \\
\text { ) }\end{array}$ & $\begin{array}{c}\text { Judul } \\
\text { Penelitian }\end{array}$ & $\begin{array}{c}\text { Variabel } \\
\text { Penelitia } \\
n\end{array}$ & $\begin{array}{c}\text { Hasil } \\
\text { Penelitian }\end{array}$ \\
\hline 1 & $\begin{array}{l}\text { Anwar } \\
\text { (2007) }\end{array}$ & $\begin{array}{l}\text { Analisa } \\
\text { pengaruh } \\
\text { strategi } \\
\text { promosi } \\
\text { penjualan } \\
\text { terhadap } \\
\text { keputusan } \\
\text { pembelian } \\
\text { konsumen } \\
\text { di Brazil } \\
\text { Churro } \\
\text { and Pastel } \\
\text { Surabaya }\end{array}$ & $\begin{array}{l}\text { Variabel } \\
\text { X: } \\
\text { Strategi } \\
\text { Promosi } \\
\text { Variabel } \\
\text { Y : } \\
\text { Keputus } \\
\text { an } \\
\text { Pembeli } \\
\text { an }\end{array}$ & $\begin{array}{l}\text { Hasil } \\
\text { pengujian } \\
\text { menunjukka } \\
\mathrm{n} \quad \text { bahwa } \\
\text { strategi } \\
\text { promosi } \\
\text { yang } \\
\text { dijalankan } \\
\text { berpengaru } \\
\text { h positif } \\
\text { terhadap } \\
\text { keputusan } \\
\text { pembelian } \\
\text { konsumen, } \\
\text { dengan } \\
\text { pembagian } \\
\text { sampel } \\
\text { makanan } \\
\text { sebagai } \\
\text { strategi } \\
\text { promosi } \\
\text { paling } \\
\text { berpengaru }\end{array}$ \\
\hline
\end{tabular}

ISSN 1858-3199

JURNAL

MANAJEMEN BISNIS

STIE IBBI

\begin{tabular}{|c|c|c|c|c|}
\hline & & & & $\mathrm{h}$. \\
\hline 2 & \begin{tabular}{|l|} 
Syaifu \\
ddin \\
$(2008)$
\end{tabular} & $\begin{array}{l}\text { Pengaruh } \\
\text { Strategi } \\
\text { Promosi } \\
\text { Terhadap } \\
\text { Keputusan } \\
\text { Pembelian } \\
\text { Konsumen } \\
\text { Dalam } \\
\text { Membeli } \\
\text { Produk } \\
\text { Shampoo } \\
\text { Mek } \\
\text { Sunsilk } \\
\text { (Studi } \\
\text { Pada } \\
\text { Pengguna } \\
\text { Shampoo } \\
\text { Sunsilk di } \\
\text { Kota } \\
\text { Jombang) }\end{array}$ & $\begin{array}{l}\text { Variabel } \\
\text { X: } \\
\text { Strategi } \\
\text { Promosi } \\
\text { Variabel } \\
\text { Y : } \\
\text { Keputus } \\
\text { an } \\
\text { Pembeli } \\
\text { an }\end{array}$ & $\begin{array}{l}\text { Hasil } \\
\text { pengujian } \\
\text { menunjukka } \\
\text { n bahwa: } \\
\text { (1) Ada } \\
\text { pengaruh } \\
\text { positif } \\
\text { siginifikan } \\
\text { bauran } \\
\text { promosi } \\
\text { (iklan, } \\
\text { penjualan } \\
\text { personal, } \\
\text { promosi } \\
\text { penjualan, } \\
\text { dan } \\
\text { hubungan } \\
\text { masyarakat) } \\
\text { secara } \\
\text { parsial } \\
\text { terhadap } \\
\text { keputusan } \\
\text { pembelian } \\
\text { konsumen } \\
\text { dalam } \\
\text { membeli } \\
\text { shampoo } \\
\text { Sunsilk di } \\
\text { kota } \\
\text { Jombang } \\
\text { dan (2) Ada } \\
\text { pengaruh } \\
\text { positif } \\
\text { signifikan } \\
\text { bauran } \\
\text { promosi } \\
\text { (iklan, } \\
\text { penjualan } \\
\text { personal, } \\
\text { promosi } \\
\text { penjualan, } \\
\text { dan } \\
\text { hubungan } \\
\text { masyarakat) } \\
\text { secara }\end{array}$ \\
\hline
\end{tabular}




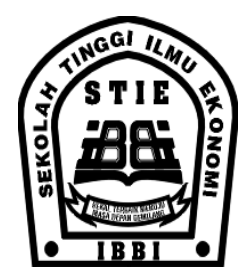

\begin{tabular}{|c|c|c|c|c|}
\hline & & & & $\begin{array}{l}\text { simultan } \\
\text { terhadap } \\
\text { keputusan } \\
\text { pembelian } \\
\text { konsumen } \\
\text { dalam } \\
\text { membeli } \\
\text { shampoo } \\
\text { Sunsilk di } \\
\text { kota } \\
\text { Jombang. }\end{array}$ \\
\hline 3 & $\begin{array}{l}\text { Qalbi } \\
(2012)\end{array}$ & $\begin{array}{l}\text { Analisis } \\
\text { Loyalitas } \\
\text { Pelanggan } \\
\text { Terhadap } \\
\text { Keputusan } \\
\text { Pembelian } \\
\text { Pada PT. } \\
\text { Sinar } \\
\text { Bintang } \\
\text { Selatan di } \\
\text { Makassar. }\end{array}$ & $\begin{array}{l}\text { Variabel } \\
\text { X: } \\
\text { Loyalita } \\
\text { S } \\
\text { Pelangg } \\
\text { an } \\
\text { Variabel } \\
\text { Y : } \\
\text { Keputus } \\
\text { an } \\
\text { Pembeli } \\
\text { an }\end{array}$ & $\begin{array}{l}\text { Hasil } \\
\text { analisis uji } \\
\text { regresi } \\
\text { antara } \\
\text { faktor } \\
\text { loyalitas } \\
\text { pelanggan } \\
\text { (kualitas } \\
\text { produk, } \\
\text { citra produk } \\
\text { dan } \\
\text { periklanan) } \\
\text { dengan } \\
\text { loyalitas } \\
\text { pelanggan } \\
\text { ternyata } \\
\text { ditemukan } \\
\text { ada } \\
\text { pengaruh } \\
\text { positif dan } \\
\text { signifikan } \\
\text { antara } \\
\text { ketiga } \\
\text { variabel } \\
\text { dengan } \\
\text { keputusan } \\
\text { pembelian } \\
\text { yakni } \\
\text { sebesar } \\
\text { 90,90\%, } \\
\text { sedangkan } \\
\text { sisanya } \\
\text { sebesar } \\
\text { 9,10\% }\end{array}$ \\
\hline
\end{tabular}

ISSN 1858-3199

JURNAL

MANAJEMEN BISNIS

STIE IBBI

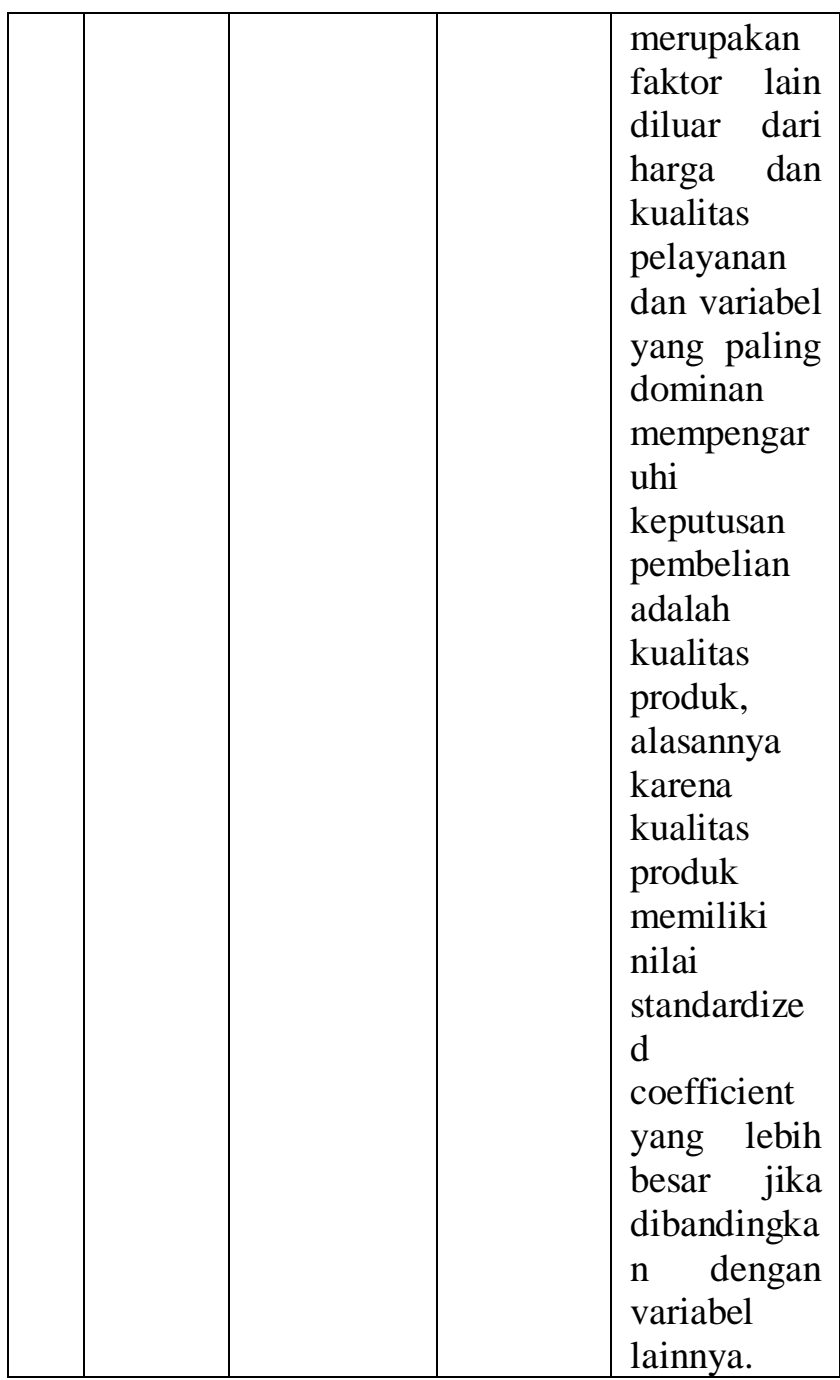

\section{H. Kerangka Pemikiran}

Strategi promosi merupakan inisiatif komunikasi organisasi, kombinasi periklanan, personal selling, promosi penjualan untuk berkomunikasi dengan konsumen dan pihak-pihak yang mempengaruhi pembelian. Strategi promosi meliputi perencanaan, implementasi dan pengendalian komunikasi organisasi ke customernya dan audiens sasaran lainnya.

Loyalitas pelanggan merupakan fungsi dari kepuasan pelanggan, rintangan pengalihan dan keluhan pelanggan. Pelanggan yang puas akan dapat melakukan pembelian ulang pada waktu yang akan 


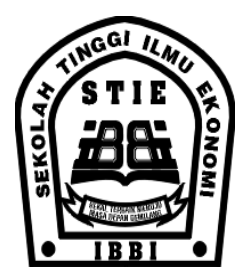

datang dan memberitahukan kepada orang lain atas jasa yang dirasakan.

Keputusan pembelian merupakan keputusan konsumen untuk membeli suatu produk setelah sebelumnya memikirkan tentang layak tidaknya membeli produk itu dengan mempertimbangkan informasi-informasi yang ia ketahui dengan realitas tentang produk itu setelah ia menyaksikannya.

Jika informasi yang diperoleh telah sesuai maka suatu keputusan pembelian akan terjadi. Keputusan pembelian merupakan hasil perhitungan yang rasional sehingga konsumen akan memilih produk yang dapat memberikan kegunaan yang paling besar, sesuai dengan selera dan biaya yang relatif berdasarkan informasi yang diperoleh. Dalam hal ini akan dibahas mengenai pengaruh strategi promosi dan loyalitas pelanggan terhadap keputusan pembelian pada PT Alfo Citra Abadi. Dengan demikian, hubungan yang terbina dengan baik dalam strategi promosi dan loyalitas pelanggan merupakan salah satu faktor yang dapat menentukan keputusan untuk melakukan pembelian produk PT Alfo Citra Abadi. Dari uraian yang telah dikemukakan di atas, maka dapat diungkapkan suatu kerangka konseptual sebagai penentuan alur pikir dan dasar penelitian ini. Dari uraian yang telah dikemukakan di atas, maka dapat diungkapkan suatu kerangka Pemikiran sebagai penentuan alur pikir dan dasar penelitian ini. Adapun kerangka pemikiran tersebut dapat digambarkan sebagai berikut:

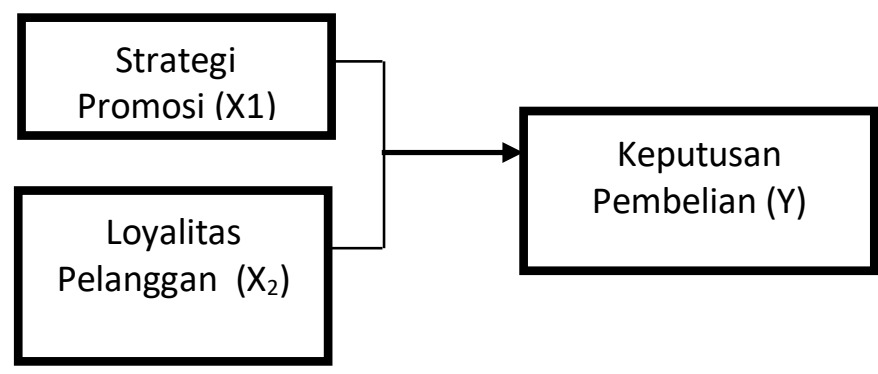

\section{Gambar 1. Kerangka Pemikiran}

\section{Metodologi Penelitian}

Lokasi penelitian ini dilakukan di PT Alfo Citra Abadi Medan. Sedangkan waktu penelitian dimulai dari bulan Januari 2018 sampai dengan bulan Juni 2018.
ISSN 1858-3199

JURNAL

MANAJEMEN BISNIS

STIE IBBI

Populasi dalam penelitian ini adalah seluruh pelanggan yang membeli produk PT Alfo Citra Abadi Medan. Teknik penarikan sampel menggunakan rumus yang menghasilkan sampel sebanyak 96 orang. Teknik pengumpulan data melalui wawancara (Interview), daftar pertanyaan (Questionnaire) dan studi dokumentasi.

Kumpulan data yang sudah diperoleh kemudian di analisis dengan menggunakan metode analisis deskriptif dan metode analisis kuantitatif. Alat uji yang dipergunakan untuk menganalisis hipotesis dalam penelitian ini adalah analisis regresi linier berganda untuk menguji variabel bebas strategi promosi dan loyalitas pelanggan terhadap variabel terikat keputusan pembelian setelah memenuhi asumsi klasik menyangkut normalitas, multikolinieritas dan heteoskedastisitas. Penarikan kesimpulan atas hipotesa dilakukan dengan cara uji $\mathrm{t}$ dan uji $\mathrm{F}$ pada level signifikansi 5\%. Keseluruhan tabulasi dan pengolahan data menggunakan software SPSS versi 18.

\section{Hasil dan Pembahasan}

\section{A. Uji Statistik Deskriptif}

Hasil analisis statistik deskriptif dapat ditunjukkan pada tabel berikut::

\section{Tabel 1}

Karakteristik Responden

\begin{tabular}{|c|c|c|}
\hline Keterangan & Frekuensi & $\begin{array}{c}\text { Persentase } \\
(\%)\end{array}$ \\
\hline Jenis & & \\
\hline Kelamin & 67 & 69,79 \\
\hline Pria & 29 & 30,21 \\
\hline Wanita & & \\
\hline$\underline{\text { Umur }}$ & 9 & 9,38 \\
\hline$\overline{26-30}$ & 11 & 11,46 \\
\hline $31-35$ & 29 & 30,21 \\
\hline $36-40$ & 47 & 48,95 \\
\hline $41-45$ & & \\
\hline Pendidikan & 46 & 47,92 \\
\hline SMA & 48 & 37,50 \\
\hline DIII & 12 & 21,88 \\
\hline $\mathrm{S} 1$ & & \\
\hline
\end{tabular}

Sumber : Hasil Penelitian, 2018 (Data Diolah) 


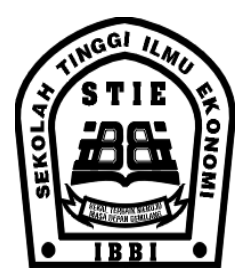

B. Uji Validitas dan Reliabilitas

Pada perhitungan validitas variabel strategi promosi, loyalitas pelanggan dan keputusan pembelian dengan 14 pertanyaan dan semua pertanyaan adalah valid dengan nilai koefisien korelasi (r) lebih besar dari 0,1986 dan dapat digunakan dalam penelitian. Kesimpulan ini diperkuat dengan nilai signifikansi (1-tailed) seluruh instrumen yang lebih kecil dari nilai $\alpha$ sebesar 5 persen.

Uji reliabilitas dihasilkan nilai Cronbach's Alpha sudah memenuhi koefisisen kehandalan lebih besar dari 0,6. Hal ini berarti bahwa item pertanyaan yang digunakan akan mampu memperoleh data yang konsisten dalam arti jika pertanyaan tersebut diajukan lagi akan diperoleh jawaban yang relatif sama dengan jawaban pertama, sehingga dapat disimpulkan bahwa item atau pertanyaan-pertanyaan yang diajukan dalam penelitian tersebut adalah handal dan realibel.

\section{Uji Asumsi Klasik 1). Uji Normalitas}

Pengujian ini dilakukan untuk mengetahui apakah dalam model regresi, variabel dependen maupun independen berdistribusi normal atau tidak. Dalam penelitian ini pengujian normalitas dilakukan dengan uji kolmogorov - smirnov (goodness of fit). Hasil dapat dilihat pada tabel berikut:

\section{Tabel 2}

Hasil Uji Normalitas

\begin{tabular}{|c|c|c|c|c|}
\hline Variabel & $\begin{array}{c}\text { Kolmogoro } \\
\text { v Smirnov }\end{array}$ & Sig. & $\begin{array}{c}\text { Batas } \\
\text { Kesalaha } \\
n\end{array}$ & $\begin{array}{l}\text { Kriteri } \\
\text { a }\end{array}$ \\
\hline $\begin{array}{l}\text { Strategi } \\
\text { Promosi } \\
\text { Loyalitas } \\
\text { Pelangga } \\
\mathrm{n} \\
\text { Keputusa } \\
\mathrm{n} \\
\text { Pembelia } \\
\mathrm{n}\end{array}$ & $\begin{array}{l}1,341 \\
1,345 \\
1,330\end{array}$ & $\begin{array}{c}0,05 \\
5 \\
0,05 \\
4 \\
\\
0,05 \\
8\end{array}$ & $\begin{array}{l}0,05 \\
0,05 \\
0,05\end{array}$ & $\begin{array}{c}\text { Norma } \\
1 \\
\text { Norma } \\
1 \\
\text { Norma } \\
1\end{array}$ \\
\hline
\end{tabular}

Sumber : Hasil Penelitian, 2018 (Data Diolah)

\section{ISSN 1858-3199 \\ JURNAL \\ MANAJEMEN BISNIS \\ STIE IBBI}

Berdasarkan Tabel 2 di atas diperoleh harga kolmogorov smirnov untuk untuk variabel strategi promosi 1,341 dengan Sig 0,055 lebih besar dari 0,05 , untuk variabel loyalitas pelanggan diperoleh harga Kolmogorov-Smirnov sebesar 1,345 dengan Sig 0,054 lebih besar dari 0,05, dan untuk variabel keputusan pembelian diperoleh harga KolmogorovSmirnov sebesar 1,330 dengan Sig 0,058 lebih besar dari 0,05 . Dengan demikian data dari variabelvariabel penelitian ini berdistribusi normal.

\section{2) Uji Multikolinieritas}

Tabel 3

Uji Multikolinieritas

\begin{tabular}{|c|c|c|c|}
\hline Variabel & $\begin{array}{l}\text { Toler } \\
\text { ance }\end{array}$ & VIF & Kesimpulan \\
\hline $\begin{array}{l}\text { Strategi } \\
\text { Promosi (X1) } \\
\text { Loyalitas } \\
\text { Pelanggan } \\
\text { (X2) }\end{array}$ & $\begin{array}{l}0,723 \\
0,723\end{array}$ & $\begin{array}{c}1,38 \\
3 \\
1,38 \\
3\end{array}$ & $\begin{array}{l}\text { Tidak terjadi } \\
\text { multikolinierita } \\
\text { s } \\
\text { Tidak terjadi } \\
\text { multikolinierita } \\
\text { s }\end{array}$ \\
\hline
\end{tabular}

Sumber : Hasil penelitian, 2018, data diolah

Berdasarkan Tabel 3 di atas nilai korelasi untuk variabel personal selling dan periklanan, mempunyai nilai nilai tolerance $>0,10$ dan nilai VIF < 10 sehingga dapat disimpulkan bahwa variabel bebas tersebut tidak saling berkorelasi.

\section{3). Uji Heteroskedastisitas}

Pengujian ini dilakukan untuk mengetahui apakah dalam sebuah model regresi terjadi ketidaksamaan varian residual dari satu pengamatan ke pengamatan lain.model regresi yang baik tidak terjadi heteroskedastisitas. Uji heteroskedastisitas pada program SPSS dilakukan dengan membuat grafik scatterplot antara Zprediction (ZPRED) yang merupakan variabel bebas dan nilai residualnya (SRESID) yang merupakan variabel terikat. 


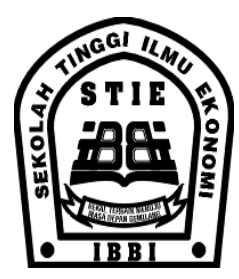

Scatterplot

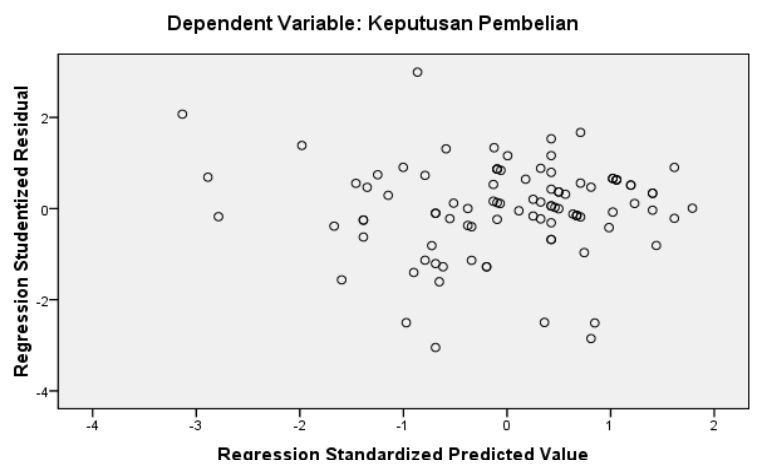

Gambar 2. Uji Heteroskedastisitas

Gambar di atas memperlihatkan titik-titik yang menyebar secara acak, tidak membentuk pola yang jelas atau teratur, serta tersebar baik di atas maupun di bawah angka 0 pada sumbu Y. Dengan demikian tidak terjadi Heterokedastisitas.

\section{Analisis Regresi Berganda}

Pengujian hipotesis regresi berganda menyatakan strategi promosi dan loyalitas pelanggan berpengaruh terhadap keputusan pembelian pada PT Alfo Citra Abadi Medan.

\section{Tabel 4}

Hasil Uji Regresi Linier Berganda

\begin{tabular}{|l|l|r|r|r|}
\hline $\begin{array}{l}\text { Mode } \\
1\end{array}$ & & \multicolumn{2}{|c|}{$\begin{array}{c}\text { Unstandardiz } \\
\text { ed } \\
\text { Coefficients }\end{array}$} & $\begin{array}{c}\text { Standa } \\
\text { rdized } \\
\text { Coeffi } \\
\text { cients }\end{array}$ \\
\cline { 3 - 5 } & & B & $\begin{array}{c}\text { Std. } \\
\text { Erro }\end{array}$ & Beta \\
& & & $r$ & \\
\hline 1 & (Constant) & 4.19 & 1.817 & \\
& Strategi & 4 & .097 & .384 \\
& Promosi & .400 & .126 & .357 \\
& Loyalitas & .483 & & \\
\hline
\end{tabular}

Sumber: Hasil Penelitian, 2018 (Data Diolah)

Berdasarkan pada Tabel 4 di atas, maka persamaan regresi linier berganda dalam penelitian ini adalah: $\mathrm{Y}=4,194+0,400 \mathrm{X}_{1}+0,483 \mathrm{X}_{2}$, strategi

\section{ISSN 1858-3199 \\ JURNAL \\ MANAJEMEN BISNIS \\ STIE IBBI}

promosi dan loyalitas pelanggan mempunyai koefisien regresi positif yang membuktikan kontribusinya terhadap keputusan pembelian (Y) pada PT Alfo Citra Abadi Medan. Hal ini menunjukkan bahwa keputusan pembelian (Y) pada Alfo Citra Abadi Medan dipengaruhi oleh variabel strategi promosi $\left(\mathrm{X}_{1}\right)$ dan loyalitas pelanggan $\left(\mathrm{X}_{2}\right)$. Peningkatan variabel strategi promosi $\left(\mathrm{X}_{1}\right)$ dan periklanan $\left(\mathrm{X}_{2}\right)$ dapat meningkatkan keputusan pembelian (Y) pada PT Alfo Citra Abadi Medan.

E. Uji statistik inferensial

Berdasarkan hasil olah data yang dilakukan dengan program SPSS Versi 18 seperti terlihat pada lampiran diperoleh hasil sebagai berikut :

Tabel 5

\begin{tabular}{|c|c|c|c|c|c|}
\hline Variabel & $\begin{array}{c}\text { Koefesien } \\
\text { Regresi }\end{array}$ & $\begin{array}{c}\text { Bet } \\
\mathrm{a}\end{array}$ & $\begin{array}{c}\mathrm{t} \\
\mathrm{gitun} \\
\mathrm{g}\end{array}$ & Sig t & $\begin{array}{c}\text { Kete } \\
\text { rang } \\
\text { an }\end{array}$ \\
\hline $\begin{array}{l}\text { Strategi } \\
\text { Promosi } \\
\left(\mathrm{X}_{1}\right)\end{array}$ & 400 & $\begin{array}{r}.38 \\
4\end{array}$ & $\begin{array}{r}4.12 \\
9\end{array}$ & .000 & $\begin{array}{c}\text { Sign } \\
\text { ifika } \\
n \\
\end{array}$ \\
\hline $\begin{array}{l}\text { Loyalitas } \\
\text { Pelanggan } \\
\left(\mathrm{X}_{2}\right)\end{array}$ & .483 & $\begin{array}{r}.35 \\
7\end{array}$ & $\begin{array}{r}3.83 \\
5\end{array}$ & .000 & $\begin{array}{c}\text { Sign } \\
\text { ifika } \\
n\end{array}$ \\
\hline $\begin{array}{l}\text { Konstanta } \\
\text { (b) }\end{array}$ & 1.134 & & & & \\
\hline $\begin{array}{l}\text { Standar } \\
\text { Error } \\
\text { Adjusted R } \\
\text { Square } \\
\mathrm{R}^{2} \\
\mathrm{R}\end{array}$ & $\begin{array}{l}\mathrm{F}_{\text {hitung }} \\
\text { Signifikan } \mathrm{F} \\
\mathrm{F}_{\text {tabel }} \\
\mathrm{t}_{\text {tabel }}\end{array}$ & $\begin{array}{l}=33,4 \\
=0.00 \\
=3,09 \\
=1,98\end{array}$ & & & \\
\hline
\end{tabular}

\section{Pengujian Model}

Sumber : Hasil penelitian, 2018 (data diolah)

\section{Pembahasan}

\section{A. Hipotesis 1}

Berdasarkan hasil analisis regresi $\mathrm{X}_{1}$ bahwa strategi promosi berpengaruh positif terhadap keputusan pembelian pada PT Alfo Citra Abadi 


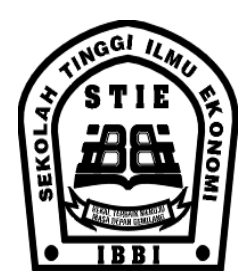

Medan. Dengan demikian jika variabel strategi promosi semakin meningkat maka keputusan pembelian akan meningkat, begitu pula sebaliknya jika pada variabel strategi promosi semakin menurun maka keputusan pembelian akan semakin menurun.

Berdasarkan hasil analisis regresi $\mathrm{X}_{2}$ bahwa loyalitas pelanggan berpengaruh positif terhadap keputusan pembelian pada PT Alfo Citra Abadi Medan. Dengan demikian jika variabel loyalitas pelanggan semakin meningkat maka keputusan pembelian akan meningkat, begitu pula sebaliknya jika pada variabel loyalitas pelanggan semakin menurun maka keputusan pembelian akan semakin menurun.

\section{B. Hipotesis 2}

Hasil uji parsial (uji t) variabel bebas strategi promosi dan loyalitas pelanggan berpengaruh terhadap variabel terikat keputusan pembelian (Y), sehingga $\mathrm{H}_{0}$ ditolak, artinya secara parsial variabel strategi promosi dan periklanan berpengaruh terhadap keputusan pembelian pada PT Alfo Citra Abadi Medan. Secara parsial variabel strategi promosi lebih berpengaruh daripada variabel loyalitas pelanggan. Artinya, variabel strategi promosi lebih berperan dalam menentukan keputusan pembelian pada PT Alfo Citra Abadi Medan dibandingkan dengan loyalitas pelanggan.

Hal ini dapat dijelaskan karena strategi promosi merupakan usaha atau kegiatan yang dilakukan perusahaan dengan maksud membujuk, merangsang konsumen agar mau membeli produk perusahaan sehingga tujuan untuk meningkatkan penjualan diharapkan dapat tercapai.

\section{Hipotesis 3}

Hasil Uji F (Serempak) yang dilakukan menghasilkan Fhitung sebesar 33,493 lebih besar dari $F_{\text {tabel }}(3,09)$ pada taraf nyata $\alpha=0,05$ dengan tingkat signifikan 0,000, yang berarti bahwa variabel strategi promosi dan loyalitas pelanggan secara bersama-sama mempunyai pengaruh signifikan terhadap keputusan pembelian (Y) pada PT Alfo Citra Abadi Medan dapat diterima atau teruji.
ISSN 1858-3199

JURNAL

MANAJEMEN BISNIS

STIE IBBI

Ini memberi arti bahwa strategi promosi dan loyalitas pelanggan sangat menentukan keputusan pembelian pada PT Alfo Citra Abadi Medan. Sesuai dengan pernyataan Lamb, Hair, McDaniel (2001 : 146), strategi promosi adalah rencana untuk penggunaan yang optimal dari elemen-elemen promosi : periklanan, hubungan masyarakat, penjualan pribadi dan promosi penjualan. Strategi promosi merupakan kegiatan yang direncanakan dengan maksud membujuk, merangsang konsumen agar mau membeli produk perusahaan sehingga tujuan untuk meningkatkan penjualan diharapkan dapat tercapai.

Hasan (2008:83) juga menyatakan loyalitas pelanggan merupakan orang yang membeli, khususnya yang membeli secara teratur dan berulang-ulang. Pelanggan merupakan seseorang yang terus menerus dan berulang kali datang ke suatu tempat yang sama untuk memuaskan keinginannya dengan memiliki suatu produk atau mendapatkan suatu jasa dan membayar produk atau jasa tersebut.

Kesimpulan strategi promosi merupakan cara perusahaan agar konsumen mau membeli produk perusahaan sedangkan loyalitas pelanggan adalah konsumen yang melakukan pembelian secara teratur dan berulang terhadap produk perusahaan. Strategi promosi yang tepat serta loyalitas konsumen terhadap produk perusahaan akan mendorong peningkatan keputusan pembelian produk perusahaan.

\section{Hipotesis 4}

Uji determinasi digunakan untuk mengetahui persentase pengaruh variabel bebas strategi promosi $\left(\mathrm{X}_{1}\right)$ dan loyalitas pelanggan $(\mathrm{X} 2)$ terhadap variabel terikat keputusan pembelian (Y). Nilai R sebesar 0,647 artinya bahwa pengaruh variabel bebas dan variabel terikat kuat, karena nilai $\mathrm{R}$ semakin mendekati nilai 1 , maka menunjukkan hubungan yang kuat.

Adjusted $R$ Square sebesar 0,406 artinya variabel strategi promosi $\left(\mathrm{X}_{1}\right)$ dan loyalitas pelanggan $\left(\mathrm{X}_{2}\right)$ mempengaruhi keputusan pembelian pada PT Alfo Citra Abadi Medan sebesar 40,6\% dan sisanya $59,4 \%$ dipengaruhi oleh variabel lain yang tidak bisa diteliti dalam penelitian ini. 


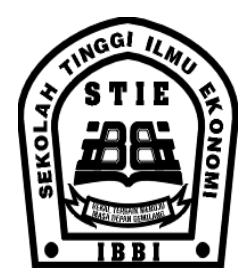

\section{Kesimpulan}

Berdasarkan hasil penelitian dan pembahasan yang telah diuraikan pada bab sebelumnya, maka dapat ditarik kesimpulan sebagai berikut : secara serempak strategi promosi dan loyalitas pelanggan berpengaruh positif terhadap keputusan pembelian pada PT Alfo Citra Abadi Medan, dengan tingkat pengaruh yang signifikan. Ini memberi arti bahwa strategi promosi dan loyalitas pelanggan sangat menentukan keputusan pembelian pada PT Alfo Citra Abadi Medan. Besarnya tingkat pengaruh variabel strategi promosi dan loyalitas pelanggan dapat dijadikan pedoman bagi pihak PT Alfo Citra Abadi Medan dalam menentukan keputusan pembelian. Secara parsial variabel strategi promosi lebih berpengaruh daripada variabel loyalitas pelanggan terhadap keputusan pembelian pada PT Alfo Citra Abadi Medan yang artinya bahwa strategi promosi lebih berperan dalam menentukan keputusan pembelian pada PT Alfo Citra Abadi Medan dibandingkan dengan loyalitas pelanggan.

\section{Referensi \\ Buku:}

Assauri, Sofjan. 2004. Perilaku Konsumen dan Strategi Pemasaran: Untuk Memenangkan Persaingan Bisnis. Edisi 2. Jakarta: Rajawali Pers

Djarwanto. 2004. Mengenal Beberapa Uji Statistik Dalam Penelitian. Yogyakarta: Penerbit Liberty.

Ghozali, Imam. 2005. Aplikasi Analisis Multivariate dengan Program SPSS. Semarang: Badan Penerbit Universitas Diponegoro

Griffin, Jill. 2002. Customer Loyalty.Jakarta: Erlangga.

Kotler, Philip, Alih Bahasa A.B. Susanto.2005. Manajemen Pemasaran di Indonesia, Analisis, Perencanaan, Implementasi dan Pengendalian. Jakarta : Penerbit Salemba Empat.

\section{ISSN 1858-3199 \\ JURNAL \\ MANAJEMEN BISNIS \\ STIE IBBI}

Lamb, Hair, dan McDaniel. 2001. Pemasaran. Buku 1. Penerjemah David Octarevia. Jakarta: Penerbit Salemba Empat

2001. Pemasaran. Buku 2. Penerjemah David Octarevia. Jakarta: Penerbit Salemba Empat

Lupioyadi, Rambat. 2003. Manajemen Pemasaran Jasa. Jakarta Penerbit Salemba Empat.

Moekijat. 2000. Manajemen Pemasaran. Bandung : Penerbit Mandar Maju

Nugroho, Setiadi 2002. Perilaku Konsumen. Jakarta: Prenada Media

Rangkuti, Freddy. 2004. Measuring Customer Satisfaction. Cetakan ketiga. Jakarta: PT.Gramedia Pustaka Utama.

Saladin, Djaslim dan Oesman, Yevis, Marty. 2003. Intisari Pemasaran. Edisi Kedua. : Medan: Media IPTEK

Sigit, Suhardi 2007. Marketing Praktis. Cetakan Pertama. Yogyakarta:Penerbit Liberty.

Sugiyono. 2008. Metode Penelitian Bisnis. Bandung: Alfabeta.

Swastha, Basu DH dan Handoko, T. Hani. 2000. Manajemen Pemasaran: Analisa Perilaku Konsumen. Edisi Pertama. Cetakan Ketiga. Yogyakarta: Penerbit BPFE.

Swastha, Basu dan Irawan. 2008. Manajemen Pemasaran Modern. Edisi II Yogyakarta: Liberty.

Tjiptono, Fandy. 2005. Strategi Pemasaran. Edisi I. Yogyakarta: Andi Offset.

Tunggal, Amin Widjaja. 2008. Konsep Dasar Customer Relationship Management $(C R M)$., Jakarta: Havarindo

\section{Non Buku:}

Chapman, Joe, and Wahler, Russ. 1999. A Revision and Empirical Test of The Extended Price Perceived Quality Model. Journal of Marketing Theory and Practice. 7,3. page 53-64

Fornell, Claes. 2002. A National Customer Satisfaction Barometer : The Swedish Experience. Journal of Marketing,Vol.56 (January).p.6-13 


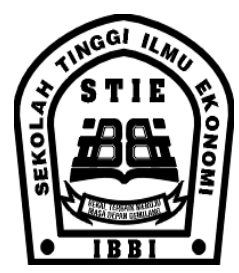

ISSN 1858-3199

Iswayanti. 2010. Analisis Pengaruh Kualitas Produk, Kualitas Layanan, Harga, dan Tempat Terhadap Keputusan Pembelian (Studi pada Rumah Makan "Soto Angkring Mas Boed" di Semarang). http://repository.undip.ac.id, diakses 30 Januari 2018

Novandri , Made Sn. 2010. Analisis Pengaruh Kualitas Produk, Harga, dan Iklan terhadap Keputusan Pembeliaan Sepeda Motor Yamaha pada Harpindo Jaya Cabang Ngaliyan. Skripsi. http://repository.undip.ac.id, diakses 28 Januari 2018

Rachmaningrum, Rosa. 2011. Analisis Pengaruh Produk, Merek, Harga, Dan Promosi Terhadap Keputusan Pembelian Sepeda Motor Honda Beat (Studi Kasus Pada Konsumen Sepeda Motor Honda Beat). Skripsi. 